\title{
Preface: Prevention and mitigation of natural and anthoropogenic hazards due to land subsidence
}

\author{
K. Daito ${ }^{1}$ and D. L. Galloway ${ }^{2}$ \\ ${ }^{1}$ Daido University, Japan \\ ${ }^{2}$ USGS, USA \\ Correspondence to: K. Daito (daito@ daido-it.ac.jp)
}

Published: 16 December 2015

An awareness of problems related to land subsidence and its anthropogenic causes has been growing worldwide since the second half of the Twentieth century. The problem of land subsidence was first included by the UNESCO program of the International Hydrological Decade (IHD), 196574. In 1969 UNESCO convened the 1st International Symposium on Land Subsidence in Tokyo. In 1975 land subsidence was retained under the framework of the International Hydrological Program (IHP) as subproject 8.4 "Investigation of Land Subsidence due to Groundwater Exploitation", and UNESCO IHP formally codified the Working Group on Land Subsidence. In collaboration with UNESCO IHP, IAHS, and other scientific organizations, the UNESCEOIHP Working Group on Land Subsidence convened eight more International Symposia on Land Subsidence in different countries in Asia, Europe and North America: Anaheim, USA (1976); Venice, Italy (1984); Houston, USA (1991); The Hague, Netherlands (1995); Ravenna, Italy (2000); Shanghai, China (2005); Queretaro, Mexico (2010); and Nagoya, Japan (2015).

Though subsidence is a global phenomenon, the consequences and their remediation generally are local. Land subsidence has become an important area of research in Japan, and globally. The proceedings of the Ninth International Symposium on Land Subsidence (NISOLS, Nagoya, 2015) represents a body of high quality and globally relevant scientific and technical information for scientists, engineers, and other stakeholders concerned about land subsidence and the associated hazards. The papers in this volume cover international science and social issues related to land subsidence and the role of natural resources development.

The main topics addressed by NISOLS includes Land Subsidence processes related to (1) Aquifer-system compaction and subsidence caused by groundwater withdrawal,
(2) Risk management of subsidence related hazards, (3) Anthropogenic land subsidence in coastal regions, (4) Land subsidence related to soil oxidation, (5) Anthropogenic uplift ( $\mathrm{CO}_{2}$-sequestration included), (6) Land subsidence and liquefaction, due to the East Japan Great Earthquake of March 11,2011 , (7) Ground failure (fracturing, fault activation, fissuring), (8) Land surface displacement, measuring and monitoring, (9) Numerical modelling, (10) Social, cultural and economic influence of land subsidence, (11) Water management strategies, (12) Subsurface deformation due to shale gas production, (13) Settlements and geotechnical construction activities and (14) Seismic activity, triggered by fluid extraction and injections. Many presenters describe the development of new techniques for monitoring, analysis, interpretation and prediction of subsidence and (or) related fracturing processes - an emphasis of NISOLS.

This symposium and the proceedings are of particular interest for Japan because of the close relation between land subsidence, ground fracturing, and groundwater use and management. These phenomena provoke widespread problems in the rapidly growing urbanized areas of central Japan. The analysis of these phenomena requires a multidisciplinary approach to improve understanding of the triggering factors, failure modes, and propagation processes of fracturing. Resolution of the often conflicting socio-economic demands placed on our natural resources and the desires to protect and preserve our natural resources is an inevitable condition for the sustainable development in developed areas. To face this challenge in Japan and elsewhere we need to improve our understanding of Land Subsidence processes. An effort was made in NISOLS to integrate a broad spectrum of the subsidence-interest community; three peripheral technical meetings were convened to focus on subsidence-related topics: (1) Workshop on Subsidence Monitoring, (2) Work- 
shop on MODFLOW Subsidence Simulation, and (3) Workshop on Geotechnical Databases.

On behalf of Inter Group Corporation, Daido University and the UNESCO-IHP Working Group on Land Subsidence we are pleased to present the proceedings of NISOLS 2015 and hope that you find much relevant and useful information in the contributed papers.

\section{Acknowledgements}

The Organizing Committee is grateful to the many people who gave their time, effort and knowledge to produce a successful program, productive workshops and enjoyable field trips. The Scientific Advisory Board diligently peer reviewed each of the contributed abstracts and papers. The Local Organizing Committee accomplished the overwhelming tasks of arranging, coordinating, directing and hosting the symposium and processing the contributed abstracts, presentations and papers.

The Editors are especially grateful for the sponsorship and endorsement provided for the symposium by the following organizations and companies:

\section{Sponsoring organizations}

- Daido University

- Daiko Foundation

- FORUM8 Co. Ltd.

- Japan Natural Gas Association/Keiyo Natural Gas Association

- Kajima Foundation

- Sakabe Environmental Technology Office

- The Association for Cavity Filling Technology

- Tokai Three-Prefecture Investigation Committee on Land Subsidence

\section{Endorsing organizations}

- UNESCO, United Nations Educational, Scientific and Cultural Organization

- Japanese National Commission for UNESCO

- Ministry of the Environment Government of Japan

- Aichi Prefecture

- City of Nagoya

- Tokai Three Prefecture Investigation Committee on Land Subsidence of Japan

- The Japanese Geotechnical Society
- Japanese Association of Groundwater Hydrology

- Japan Society of Civil Engineers

- Japan Society of Engineering Geology

Booth exhibition attending organizations

- UNESCO-IHP Working Group on Land Subsidence

- Japan National Commission for UNESCO

- Tokai Three-Prefecture Investigation Committee on Land Subsidence

- Aichi Prefectural Government, Department of Environment

- City of Nagoya, Department Regional Environment Policies Division, Environmental Affairs Bureau Regional Environment Policies

- Daido University, Department of Architecture, Civil Engineering and Environmental Design Course

- Japan Natural Gas Association/Keiyo Natural Gas Association, Environment Committee

- The Association for Cavity Filling Technology

- FORUM8 Co. Ltd.

Organizing committee

- Devin L. Galloway - Chairman, USGS, USA

- Dora Carreón-Freyre - Vice Chairman, UNAM, Mexico

- Kenji Daito, Daido University, Japan

- Pietro Teatini, University of Padova, Italy

Local organizing committee

- Kenji Daito - Chair, Daido University, Japan

- Takeshi Sato, Gifu University, Japan

- Takeshi Makinouchi, Meijo University, Japan

- Kano Ueshita, Nagoya University, Japan

- Ryuichi Sugisaki, Nagoya University, Japan

- Fusetsu Takagi, Nagoya University, Japan

- Mamoru Adachi, Nagoya University, Japan

- Katsuro Ogawa, Nagoya University, Japan

- Tsutomu Sugiura, Aichi University of Education, Japan

- Kazuki Mori, Mie University, Japan 
- Masatoshi Shidawara, Aichi Institute of Technology, Japan

- Kazuya Yasuhara, Ibaraki University, Japan

- Makoto Nishigaki, Okayama University, Japan

- Tomochika Tokunaga, The University of Tokyo, Japan

Scientific advisory board

- Alice Aureli, UNESCO IHP, France

- Mahmoud Bakr, Dar Al-Handasah Consultants LTD, Egypt

- Tom Burbey, Virginia Tech. University, USA

- Enrique Cabral-Cano, UNAM, Mexico

- Peter Fokker, TNO, The Netherlands

- Giuseppe Gambolati, University of Padova, Italy

- Kelvin Hung, Green Environment Engineering Consultant Co. LTD., Taiwan

- John Lambert, Deltares-GeoDelft, The Netherlands

- Ger de Lange, Deltares, Institute for Delta Technology, The Netherlands

- Keith Prince, USGS, USA

- Michelle Sneed, USGS, USA

- Roberto Tomás-Jover, University of Alicante, Spain

- Xue-Xin Yan, Shanghai Institute of Geological Survey, China

- Shujun Ye, Nanjing University, China

- A-Gen Zhang, China Geological Survey, Shanghai Institute, China

Special thanks to Kengo Suzuki and Mizuru Suzuki of Inter Group Corporation for providing the technical-scientific secretarial support for the symposium and invaluable assistance in the publication of this proceedings volume. 